\title{
EVALUASI PERUBAHAN GARIS PANTAI AKIBAT ABRASI DENGAN CITRA SATELIT MULTITEMPORAL (STUDI KASUS: PESISIR KABUPATEN GIANYAR, BALI)
}

\author{
Teguh Hariyanto ${ }^{1}$, Cherie Bhekti Pribadi ${ }^{2}$,Mutia Kamalia Mukhtar ${ }^{3}$, \\ 1,2,3 Departemen Teknik Geomatika FTSLK-ITS, Kampus ITS Sukolilo, Surabaya, 60111 \\ e-mail : teguh_hr@geodesy.its.ac.id ${ }^{1}$, cheriepribadi@gmail.com² ${ }^{2}$,mutiakamalia@gmail.com ${ }^{1}$
}

Abstrak

Pantai merupakan suatu kawasan peralihan atau pertemuan antara darat dan laut. Pada Kabupaten Gianyar, Bali membentang laut sepanjang selatan Pulau Bali yang merupakan daerah yang berbatasan langsung dengan wilayah pesisir. Tentunya hal tersebut tidak lepas dari adanya dinamika perubahan pada fisik pantai yang disebabkan seperti pengikisan daratan oleh air laut (abrasi) maupun adanya angkutan sedimen dari darat (akresi) yang pada umumnya menjadi sorotan terhadap perubahan garis pantai. Untuk itu diperlukan penelitian guna mengetahui besarnya perubahan yang terjadi sepanjang garis pantai tahun 2002 sampai 2017 sehingga menghasilkan peta perubahan garis pantai. Metode yang digunakan adalah menggunakan interpretasi ratio pada kanal SWIR dan hijau pada citra Landsat 7 dan Landsat 8 ditambah dengan melakukan klasifikasi, dapat dilakukan untuk mengidentifikasi garis pantai beserta menganalisis besarnya perubahan yang terjadi. Hasil analisis tumpang susun identifikasi garis pantai di Kabupaten Gianyar menunjukkan luas pesisir pada tahun 2002 sebesar 42,441 km² dan pada tahun 2017 sebesar 42,285 km² dimana terjadi abrasi sebesar 0,195 km² yang diakibatkan oleh faktor alam yaitu pesisir Kabupaten Gianyar berada di zona laut lepas.

Kata Kunci- Garis Pantai, Abrasi, Penginderaan Jauh, Sistem Informasi Geografis, Landsat, Kabupaten Gianyar

\section{Abstract}

The coast is a region of transition or encounter between land and sea. At Gianyar, Bali the sea along the South of the island of Bali is directly adjacent to the coastal area. Surely it is not separated from the presence of a physical change in the dynamics of the beach caused such annihilation of mainland by sea water (abrasion) as well as the presence of sediment transport from overland (accretion) which generally became the spotlight to changes the coastline. It is necessary to research in order to find out the large of the changes that occur along the coastline of the year 2002 until 2017 to produce a map of the coastline changes. The method that used is use the band ratio on SWIR band and the green band on Landsat 7 and 8 and classifiying land cover to identify the coastline along with analyzing the large of the changes that happened. An analysis of the results of the identification of overlay the coastline in Gianyar show the large of coastal in 2002 is $42.441 \mathrm{~km}^{2}$, and in 2017 is $42.285 \mathrm{~km}^{2}$ which occurred $0.195 \mathrm{~km}^{2}$ of abrasion caused by natural factors, such as Gianyar are in the high sea zone.

Keywords-Coastline, Abrasion, Remote Sensing, Geographic Information Systems, Landsat, Gianyar Regency, Bali

\section{PENDAHULUAN}

Garis pantai merupakan kawasan yang mempunyai beberapa ekosistem tersendiri dimana setiap kehidupan pantai saling berkaitan antara satu sama lain, antara satu ekosistem dengan ekosistem lainnya saling mempunyai keterkaitan serta berbagai fungsi yang kadang- kadang saling menguntungkan maupun merugikan. Oleh karena itu, kawasan pantai merupakan satu kawasan yang sangat dinamik begitu pula dengan garis pantainya.
Perubahan terhadap garis pantai adalah satu proses tanpa henti (terus menerus) melalui berbagai proses baik pengikisan (abrasi) maupun penambahan (akresi) pantai yang diakibatkan oleh pergerakan sedimen, arus susur pantai (longshore current), tindakan ombak dan penggunaan tanah (Vreugdenhil 1999). Perubahan pada garis pantai yang diakibatkan oleh faktor-faktor tersebut di atas dapat menunjukkan kecenderungan perubahan garis pantai tersebut terkikis (mengarah ke daratan) atau bertambah (menjorok ke laut). Informasi perubahan garis pantai sangat penting 
dalam berbagai kajian pesisir, misalnya; rencana pengelolaan kawasan pesisir, pewilayahan bahaya, studi abrasi-akresi, serta analisis dan pemodelan morfodinamik pantai (Chand, dkk 2010).

Pesisir daratan pantai selatan pada sepanjang pantai di Kabupaten Gianyar, Bali cukup memiliki perubahan yang signifikan akibat dari adanya dampak dua hal tersebut. Dari $14.284 \mathrm{~km}$ luas pantai di Kabupaten Gianyar, yang mengalami abrasi seluas $10.480 \mathrm{~km}$ (Dinas PU Gianyar 2017). Akibat dari pengikisan pantai tersebut adalah runtuhnya pura-pura ditepi pantai dan warungwarung yang menjadi tempat peristirahatan saat rekreasi ke pantai-pantai di Kabupaten Gianyar, Bali.

Klasifikasi wilayah pesisir dan pantai di Indonesia dapat lebih mudah dikenali dengan menggunakan metode penginderaan jauh dengan proses secara temporal dan spasial. Teknologi penginderaan jauh sangat mendukung dalam identifikasi dan penilaian sumber daya di wilayah pesisir dan perubahan garis pantai, karena memiliki keunggulan yaitu dapat meliputi daerah yang luas dengan resolusi spasial yang tinggi, serta memberikan banyak pilihan jenis satelit penginderaan jauh yang mempunyai keakuratan yang cukup baik dalam mengidentifikasi obyekobyek di permukaan bumi (Anugrahadi 2012).

Satelit Landsat memiliki kemampuan untuk mendeteksi perubahan garis pantai dengan menggunakan metode band ratio, oleh karena itu penelitian ini menggunakan satelit Landsat untuk mengetahui perubahan garis pantai tahun 2002 dan 2017 di Kabupaten Gianyar, Bali.

\section{METODOLOGI PENELITIAN}

\section{Lokasi Penelitian}

Lokasi penelitian Tugas Akhir ini berlokasi di Kabupaten Gianyar, Bali terletak diantara $115^{\circ} 13^{\prime} 29^{\prime \prime}$ BT-115'22'23"BT dan 8 $8^{\circ} 18^{\prime} 48^{\prime \prime}$ LS $8^{\circ} 38^{\prime} 58^{\prime \prime}$ LS. Batas-batas administrasi sebagai berikut: (Bappeda Kab. Gianyar 2014)

- Sebelah Utara : Kabupaten Bangli.

- Sebelah Timur : Kabupaten Klungkung.

- Sebelah Selatan : Kota Denpasar dan Selat Badung.

- Sebelah Barat : Kabupaten Badung.

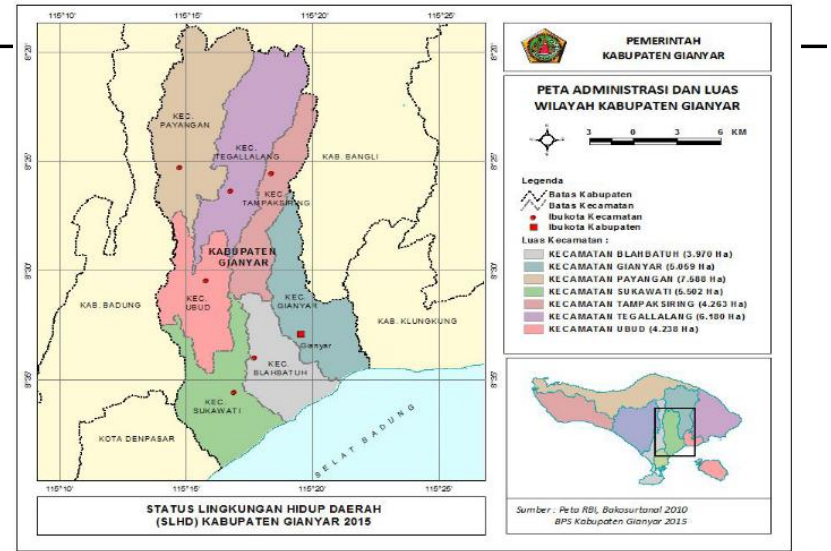

Gambar 1. Lokasi Penelitian (BLH Kab. Gianyar, Bali,

\section{Tahap Pengolahan Data}

Adapun tahapan pengolahan data sebagai berikut:

a. Pengambilan Data

Data yang digunakan pada penelitian ini berupa data citra satelit Landsat 7 untuk tahun 2002 dan citra satelit Landsat 8 untuk tahun 2017 yang bersumber dari USGS, peta vektor batas administrasi wilayah Kabupaten Gianyar yang bersumber dari BIG, data ground truth yang bersumber dari pengukuran di lapangan, peta rupa bumi Indonesia wilayah Kabupaten Gianyar yang bersumber dari BIG, serta data pasang surut wilayah Kabupaten Gianyar yang bersumber dari BIG.

b. Penggabungan Band

Penggabungan citra satelit Landsat 7 dan Landsat 8 dilakukan untuk menggabungkan band - band yang terpisah menjadi satu file. Band yang digabungkan adalah band biru, hijau, merah dan SWIR-1. Dalam hal ini band yang digabungkan ada 4 band yaitu band 1, 2, 3, dan 5 untuk citra satelit Landsat 7, sedangkan citra satelit Landsat 8 ada 7 band yang digabungkan yaitu band 2, 3, 4, dan 6. (Alesheikh,2007)

c. Pemotongan Citra

Pemotongan citra dilakukan untuk mendapatkan citra yang sesuai dengan studi kasus yang dipilih. Adapun studi kasus yang digunakan yaitu pantai di sepanjang Kabupaten Gianyar, Bali. Pemotongan citra menggunakan subset vektor dari batas daerah Kecamatan Sukawati, Kecamatan Blahbatuh, dan Kecamatan Gianyar.

d. Pemisahan Darat dan Laut (Band Ratio) 
Band Ratio berfungsi untuk memisahkan antara wilayah daratan dan lautan. Formula yang digunakan untuk mengidentifikasi garis pantai yang tertutup oleh pasir dan tanah adalah band hijau dibagi band SWIR-1. Dalam hal ini, band ratio pada citra satelit Landsat 7 menggunakan formula band 2 dibagi band 5 . Sedangkan pada citra satelit Landsat 8 menggunakan band 3 dibagi band 6.(Anugrahadi,2012)

e. Konversi Raster ke Vektor

Mengubah citra yang telah teridentifikasi daratan dan lautan menjadi bentuk vektor (.shp) dengan menggunakan tools Raster to Polyline dan Raster to Polygon pada perangkat lunak ArcGIS 10.3 sehingga akan menghasilkan garis pantai dari masingmasing citra.

f. Klasifikasi Supervised (Terbimbing)

Klasifikasi ini dilakukan untuk melihat perubahan tutupan lahan disekitar pesisir pantai. Klasifikasi ini dimulai dengan cara membuat ROI dari pixel tiap-tiap kelas, yaitu vegetasi, pemukiman, badan air, dan badan jalan. Lalu dilakukan klasifikasi dengan tool supervised classification: maximum likelihood akan terbentuk poligon-poligon dari hasil klasifikasi masing-masing kelas tersebut.

g. Uji Akurasi

Uji akurasi menggunakan matriks omisi dan komisi yang bertujuan untuk mengetahui apakah proses klasifikasi sudah akurat atau belum. Apabila hasilnya diatas $85 \%$ maka sudah masuk toleransi. Uji akurasi dilakukan dengan membuat tabel omisi dan komisi yang membandingkan hasil interpretasi citra dengan hasil uji lapangan, lalu menghasilkan overall accuracy.

h. Analisa Spasial

Menganalisa perubahan tutupan lahan wilayah pesisir Kabupaten Gianyar, Bali tahun 2002 dan 2017 serta menganalisa perubahan garis pantai akibat abrasi Kabupaten Gianyar, Bali tahun 2002 dan 2017.

i. Pembuatan Peta Perubahan Garis Pantai Tahun 2002 sampai 2017 dan Peta Perubahan Tutupan Lahan Tahun 2002 sampai 2017

Dari hasil overlay citra, maka selanjutnya dilakukan proses layouting peta. Peta yang dihasilkan berupa peta perubahan garis pantai akibat abrasi di wilayah
Kabupaten Gianyar, Bali tahun 2002 sampai 2017 yang telah dikoreksi dengan data pasang surut air laut serta peta perubahan tutupan lahan di wilayah Kabupaten Gianyar, Bali tahun 2002 sampai 2017 yang di overlay dengan peta RBI 1:25000 wilayah Kabupaten Gianyar, Bali.

j. Perhitungan Luas Area Perubahan Garis Pantai Tahun 2002 sampai 2017

Perhitungan luas ini digunakan untuk mengetahui seberapa besar perubahan garis pantai akibat abrasi dan perubahan tutupan lahan menggunakan perangkat lunak ArcGIS 10.3 yang akan menghasilkan luas dari masingmasing perubahan. Hasilnya disajikan dalam bentuk tabel.

\section{HASIL DAN PEMBAHASAN}

\section{Pemisahan Daratan dan Lautan (Band Ratio)}

Perubahan garis pantai akibat abrasi di Kabupaten Gianyar dapat diketahui melalui citra satelit Landsat 7 dan Landsat 8 dengan menggunakan metode band ratio. Band ratio digunakan untuk memisahkan daratan dan lautan, agar menghasilkan garis pantai dari citra. Metode ini menggunakan nilai dari reflektan permukaan pada citra yang telah terkoreksi radiometrik.

Pada penelitian ini, kedua citra yang digunakan merupakan level L1TP yang mana sudah terortorektifikasi dan terkoreksi radiometrik menggunakan GCP dari data GLS2000 serta DEM yang meliputi SRTM, NED, CDED, DTED, GTOPO 30, and GIMP (USGS 2017).

Formula yang digunakan pada metode ini adalah band hijau dibagi band SWIR-1, formula ini dapat mendeteksi garis pantai yang tertutup pasir dan tanah (Alesheikh, dkk, 2007) dimana pada studi kasus penelitian ini, pantai yang terdapat di Kabupaten Gianyar merupakan pantai yang tertutup pasir dan tanah. Formula pada Landsat 7 menggunakan band 2 dibagi band 5 dan pada Landsat 8 menggunakan band 3 dibagi band 6 . Berikut ini adalah hasil penggunaan formula band ratio terhadap citra satelit Landsat 7 dan 8: 


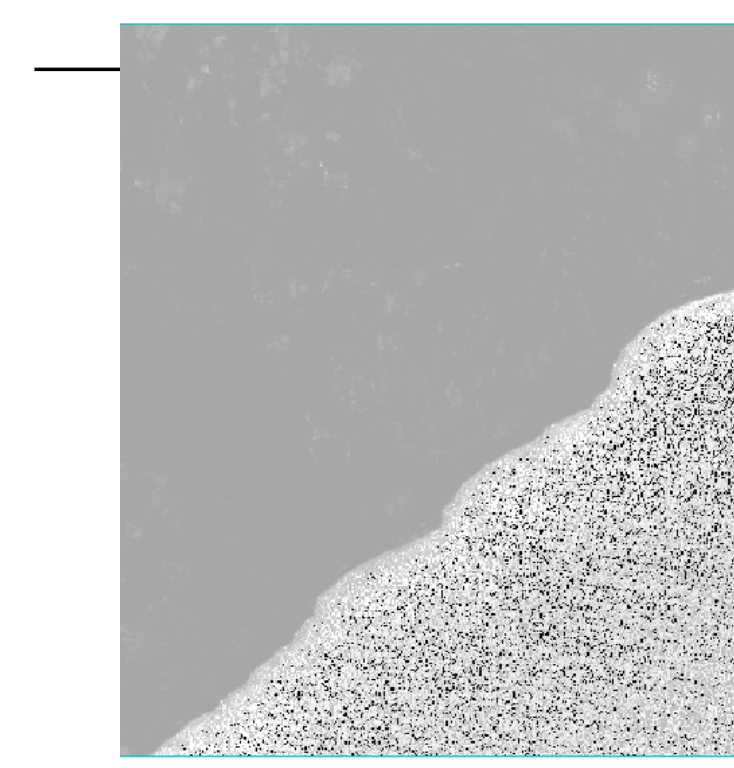

Gambar 2. Hasil Band Ratio Citra Landsat 7

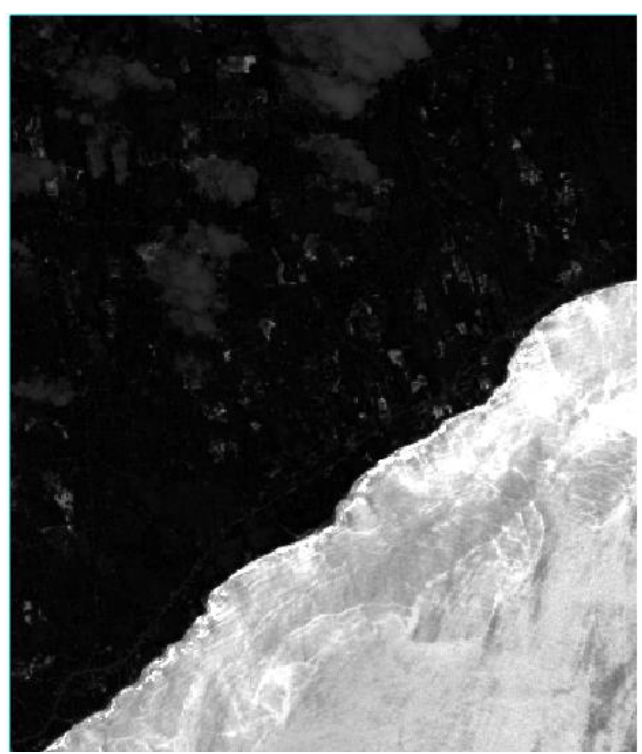

Gambar 3. Hasil Band Ratio Citra Landsat 8

Pada gambar 4 dari Landsat 7 dihasilkan wilayah daratan yang berwarna abu-abu pekat, dan wilayah lautan yang berwarna titik-titik abu-abu. Sedangkan, pada gambar 5 dari Landsat 8 dihasilkan wilayah daratan yang berwarna hitam dan wilayah lautan yang berwarna putih. Dari proses ini, dapat dihasilkan garis pantai yang jelas.

\section{Konversi Raster ke Vektor}

Konversi raster ke vektor digunakan untuk mendapatkan garis pantai yang dapat dihitung dan dioverlay sehingga akan memudahkan dalam melakukan analisa perubahan garis pantai akibat abrasi dan pembuatan peta perubahan garis pantai akibat abrasi. Berikut ini adalah hasil dari konversi raster ke vektor pada citra satelit Landsat 7 dan 8:

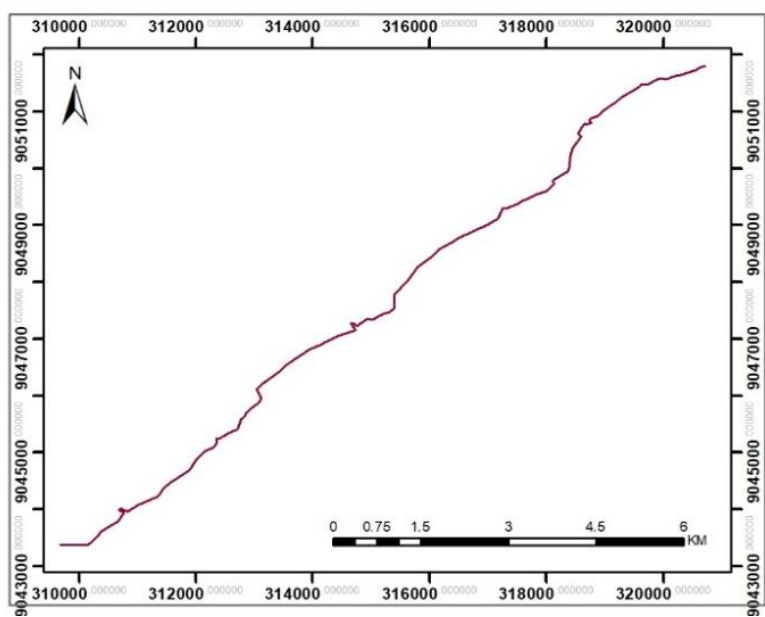

Gambar 4. Vektor Garis Pantai Landsat 7 Tahun 2002

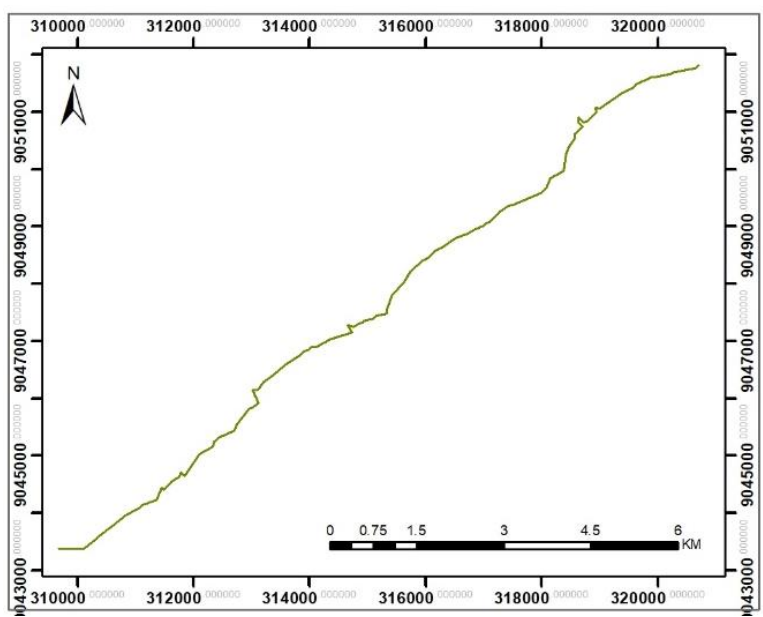

Gambar 5. Vektor Garis Pantai Landsat 8 Tahun 2017

Pada gambar 6 merupakan vektor garis pantai dari citra satelit Landsat 7 tahun 2002, dan gambar 7 merupakan vektor garis pantai dari citra satelit Landsat 8 tahun 2017.

\section{Perubahan Garis Pantai}

Perubahan garis pantai akibat abrasi di Kabupaten Gianyar dapat diketahui melalui citra satelit Landsat 7 tahun 2002 dan Landsat 8 tahun 2017 dengan menggunakan metode band ratio yang di konversi menjadi vektor, sehingga dapat diketahui luas abrasi yang terjadi. Berikut ini adalah Peta Perubahan Garis Pantai Tahun 2002-2017 Kabupaten Gianyar: 


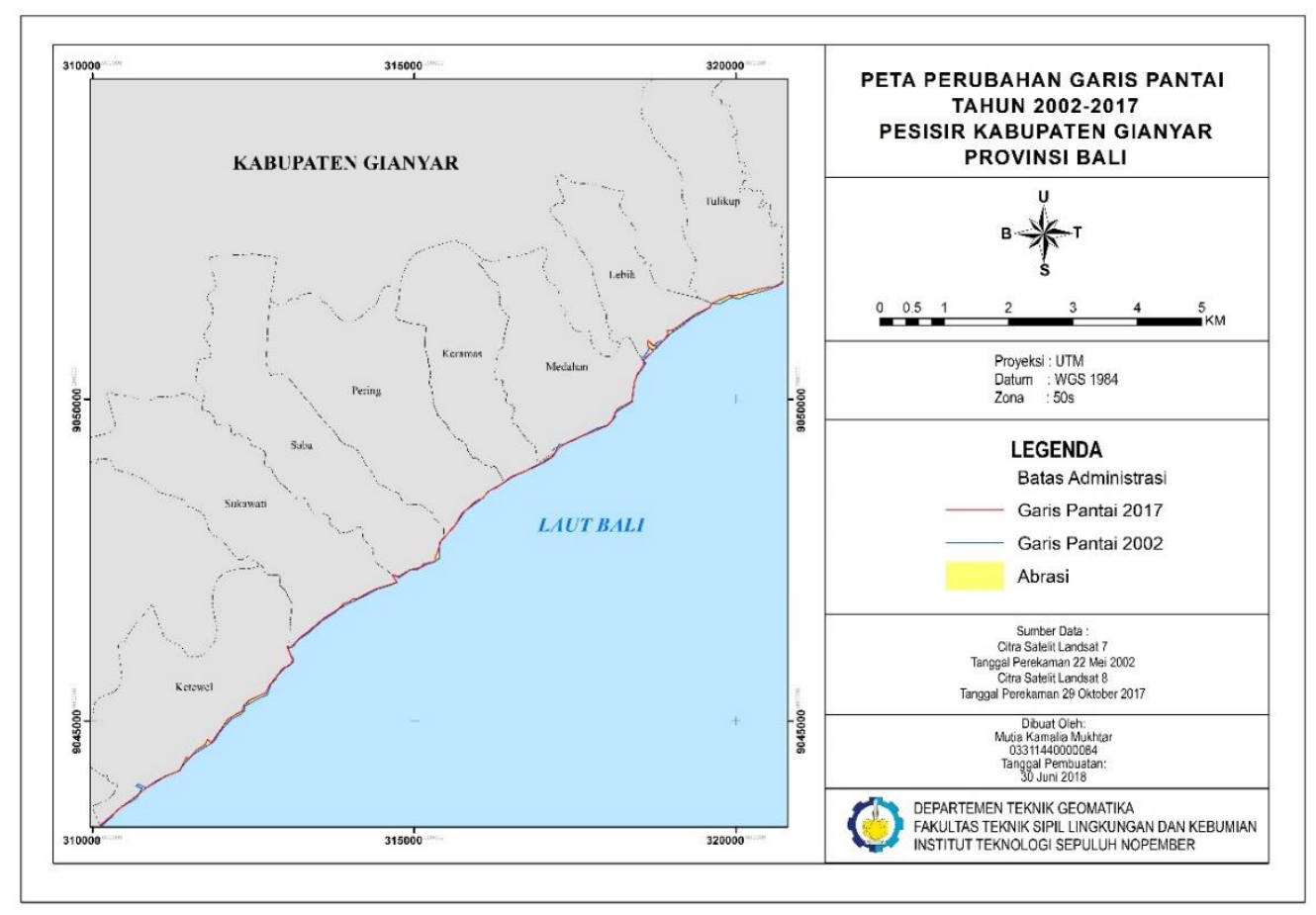

Gambar 6. Perubahan Garis Pantai Tahun 2002-2017

Hasil pengolahan citra menunjukkan luas dari abrasi yang terjadi pada pesisir Kabupaten Gianyar yang disajikan pada tabel berikut:

Tabel 1. Perubahan Luas Akibat Abrasi

\begin{tabular}{cccc} 
Kabupaten & Kecamatan & Desa & $\begin{array}{c}\text { Luas Abrasi } \\
\left(\mathrm{km}^{2}\right)\end{array}$ \\
\hline \multirow{6}{*}{ Sianyar } & \multirow{2}{*}{ Sukawati } & Ketewel & 0,065 \\
& & Sukawati & 0,025 \\
& & Saba & 0,015 \\
& & Pering & 0,006 \\
& & Keramas & 0,007 \\
& & Medahan & 0,011 \\
& Gianyar & Lebih & 0,026 \\
& Tulikup & 0,040 \\
\hline \multicolumn{3}{c}{ Total } & 0,195 \\
\hline
\end{tabular}

Hasil pengolahan citra satelit Landsat 7 tahun 2002 dan Landsat 8 tahun 2017 menunjukkan luas abrasi yang terjadi cukup besar dari tahun 2002 sampai 2017 adalah sebesar 0,195 $\mathrm{km}^{2}$. Desa yang paling banyak terkena abrasi adalah Desa Ketewel sebesar $0,065 \mathrm{~km}^{2}$ Desa Tulikup sebesar $0,040 \mathrm{~km}^{2}$, Desa Lebih sebesar $0,026 \mathrm{~km}^{2}$, Desa Sukawati sebesar $0,025 \mathrm{~km}^{2}$, Desa Saba sebesar 0,015 km², Desa Medahan sebesar 0,011 $\mathrm{km}^{2}$, Desa Keramas $0,007 \mathrm{~km}^{2}$, dan yang paling sedikit terkena abrasi adalah Desa Pering sebesar 70
$0,006 \mathrm{~km}^{2}$. Perubahan garis pantai akibat abrasi terjadi murni karena faktor alam yaitu pantai yang terletak pada zona laut lepas.

Penarikan garis pantai dari citra satelit juga mempertimbangkan faktor alam, salah satunya adalah pasang surut air laut. Peta perubahan garis pantai Kabupaten Gianyar tahun 2002-2017 pada gambar 8 sudah terkoreksi dari hasil perhitungan pasang surut air laut. Berikut ini merupakan perhitungan koreksi pasang surut:

Tabel 2. Perhitungan Pasang Surut

\begin{tabular}{cccccc}
\hline No. & $\begin{array}{c}\text { Tanggal } \\
\text { Akuisisi }\end{array}$ & Waktu & $\begin{array}{c}\text { HHWL } \\
(\mathrm{m})\end{array}$ & $\mathrm{d}(\mathrm{m})$ & $\mathrm{m}(\mathrm{m})$ \\
\hline 1. & 22 Mei 2002 & $10: 12$ & 1,391 & 11,063 & 384,208 \\
2. & $\begin{array}{c}29 \text { Oktober } \\
2017\end{array}$ & $10: 24$ & 1,476 & 11,395 & 412,872 \\
\hline No. & $\begin{array}{c}\text { Tanggal } \\
\text { Akuisisi }\end{array}$ & Waktu & $\mathrm{n}(\mathrm{m})$ & $\beta(\mathrm{o})$ & $\mathrm{x}(\mathrm{m})$ \\
\hline 1. & $\begin{array}{c}22 \text { Mei } 2002 \\
29\end{array}$ & $10: 12$ & 0,328 & 1,649 & 0,199 \\
2. & $\begin{array}{c}\text { Oktober } \\
\text { 2017 }\end{array}$ & $10: 24$ & 0,081 & 1,581 & 0,051 \\
\hline
\end{tabular}

Berdasarkan Undang-Undang Republik Indonesia Nomor 23 Tahun 2014, garis pantai yang digunakan untuk penarikan batas pengelolaan wilayah laut dan wilayah administrasi daerah adalah batas pertemuan antara bagian laut dan daratan pada saat terjadi air laut pasang tertinggi. 
Penarikan garis pantai dilakukan dengan mengambil satu titik pada garis pantai yang diasumsikan bahwa kondisi air laut mengalami kenaikan yang sama, setelah itu dapat dihitung kemiringan pantai yang akan menghasilkan jarak pergeseran garis pantai hasil koreksi terhadap pasang surut $(\mathrm{x})$. Highest High Water Level (HHWL) didapatkan dari perhitungan pasang surut dengan metode least square, nilai kedalaman (d) didapat dari kontur yang terdapat di Peta Lingkungan Pantai Kabupaten Gianyar yang dikoreksi dengan nilai bacaan pasang surut saat perekaman citra $(n)$ dan nilai HHWL. Penarikan garis pantai tahun 2002 yang di dapat dari Landsat 7 ditarik kearah darat sebesar 0,199 m dan garis pantai tahun 2017 yang di dapat dari Landsat 8 ditarik kearah darat sebesar $0,051 \mathrm{~m}$.

Perubahan tutupan lahan di pesisir pantai selama tahun 2002 sampai 2017 mengalami perubahan yang cukup signifikan. Berikut ini perubahan yang terjadi pada tutupan lahan di pesisir pantai Kabupaten Gianyar:

Tabel 3. Luas Tutupan Lahan Tahun 2017

\begin{tabular}{ccccc}
\hline \multirow{2}{*}{ Desa } & \multicolumn{4}{c}{ Tahun 2002} \\
\cline { 2 - 5 } & $\begin{array}{c}\text { Pemukiman } \\
\left(\mathrm{km}^{2}\right)\end{array}$ & $\begin{array}{c}\text { Sawah } \\
\left(\mathrm{km}^{2}\right)\end{array}$ & $\begin{array}{c}\text { Kebun } \\
\left(\mathrm{km}^{2}\right)\end{array}$ & $\begin{array}{c}\text { Ladang } \\
\left(\mathrm{km}^{2}\right)\end{array}$ \\
\hline Ketewel & 1,639 & 4,125 & 0,589 & 0,031 \\
Sukawati & 2,539 & 2,502 & 1,315 & 0,270 \\
Saba & 1,345 & 2,721 & 2,116 & 0,045 \\
Pering & 1,044 & 3,435 & 1,486 & 0,500 \\
Keramas & 0,853 & 2,908 & 0,170 & 0,276 \\
Medahan & 0,529 & 3,514 & 0,075 & 0,067 \\
Lebih & 0,744 & 1,470 & 0,446 & 0,000 \\
Tulikup & 0,916 & 3,370 & 1,318 & 0,085 \\
\hline Total & 9,610 & 24,044 & 7,514 & 1,274 \\
\hline
\end{tabular}

Tabel 4. Luas Tutupan Lahan Tahun 2017

\begin{tabular}{ccccc}
\hline \multirow{2}{*}{ Desa } & \multicolumn{4}{c}{ Tahun 2017} \\
\cline { 2 - 5 } & $\begin{array}{c}\text { Pemukiman } \\
\left(\mathrm{km}^{2}\right)\end{array}$ & $\begin{array}{c}\text { Sawah } \\
\left(\mathrm{km}^{2}\right)\end{array}$ & $\begin{array}{c}\text { Kebun } \\
\left(\mathrm{km}^{2}\right)\end{array}$ & $\begin{array}{c}\text { Ladang } \\
\left(\mathrm{km}^{2}\right)\end{array}$ \\
\hline Ketewel & 2,352 & 1,637 & 1,095 & 1,207 \\
Sukawati & 2,109 & 2,359 & 1,793 & 0,272 \\
Saba & 1,083 & 2,573 & 1,731 & 0,921 \\
Pering & 1,174 & 0,902 & 2,145 & 1,688 \\
Keramas & 1,173 & 0,969 & 0,620 & 1,669 \\
Medahan & 1,016 & 1,764 & 0,701 & 1,073 \\
Lebih & 0,992 & 0,644 & 1,267 & 0,000 \\
Tulikup & 1,314 & 2,523 & 1,449 & 0,069 \\
Total & 11,213 & 13,370 & 10,801 & 6,899 \\
\hline
\end{tabular}

Tabel 5. Luas Perbedaan Tutupan Lahan Tahun 2002-

\begin{tabular}{cc}
\multicolumn{2}{c}{2017} \\
\hline Kelas & Neraca $\left(\mathrm{km}^{2}\right)$ \\
\hline Pemukiman & $+1,603$ \\
Sawah & $-10,674$ \\
Kebun & $+3,287$ \\
Ladang & $+5,625$ \\
\hline
\end{tabular}

Tutupan lahan pada tahun 2002 dan 2017 didominasi oleh sawah, peta tutupan lahan tahun 2002 dan 2017 dapat dilihat pada gambar 9 dan gambar 10. Berdasarkan tabel 5, terdapat beberapa perubahan luas tutupan lahan pada tahun 2002 sampai 2017. Perubahan ini terjadi akibat adanya perubahan fungsi lahan yang mana terjadi penambahan sebesar $1,603 \mathrm{~km}^{2}$ untuk pemukiman, pengurangan sebesar $10,674 \mathrm{~km}^{2}$ untuk sawah, penambahan sebesar $3,287 \mathrm{~km}^{2}$ untuk kebun, dan penambahan sebesar $5,625 \mathrm{~km}^{2}$ untuk ladang.

Perubahan tutupan lahan pada tahun 2002 sampai 2017 dapat dilihat pada gambar 11 yang meliputi perubahan kebun ke ladang, kebun ke pemukiman, kebun ke sawah, ladang ke kebun, ladang ke pemukiman, ladang ke sawah, sawah ke kebun, sawah ke ladang, dan sawah ke pemukiman.

Perubahan yang paling dominan adalah dari sawah ke ladang sebesar $4,842 \mathrm{~km}^{2}$ lalu dari sawah ke pemukiman sebesar $3,212 \mathrm{~km}^{2}$, dari kebun ke sawah sebesar 2,147 $\mathrm{km}^{2}$, dari kebun ke pemukiman sebesar $1,144 \mathrm{~km}^{2}$, dari kebun ke ladang sebesar $0,741 \mathrm{~km}^{2}$, dari sawah ke kebun $0,654 \mathrm{~km}^{2}$, dari ladang ke kebun $0,286 \mathrm{~km}^{2}$, dari ladang ke sawah sebesar $0,249 \mathrm{~km}^{2}$, dan yang paling kecil adalah dari ladang ke pemukiman sebesar $0,121 \mathrm{~km}^{2}$ yang disajikan pada tabel 6 .

Tabel 6. Luas Perubahan Tutupan Lahan dari Tahun

\begin{tabular}{cc}
\multicolumn{2}{c}{ 2002 ke 2017} \\
\hline Kelas & Luas $\left(\mathrm{km}^{2}\right)$ \\
\hline Kebun ke Ladang & 0,741 \\
Kebun ke Pemukiman & 1,144 \\
Kebun ke Sawah & 2,147 \\
Ladang ke Kebun & 0,286 \\
Ladang ke Pemukiman & 0,121 \\
Ladang ke Sawah & 0,249 \\
Sawah ke Kebun & 0,654 \\
Sawah ke Ladang & 4,842 \\
Sawah ke Pemukiman & 3,212
\end{tabular}




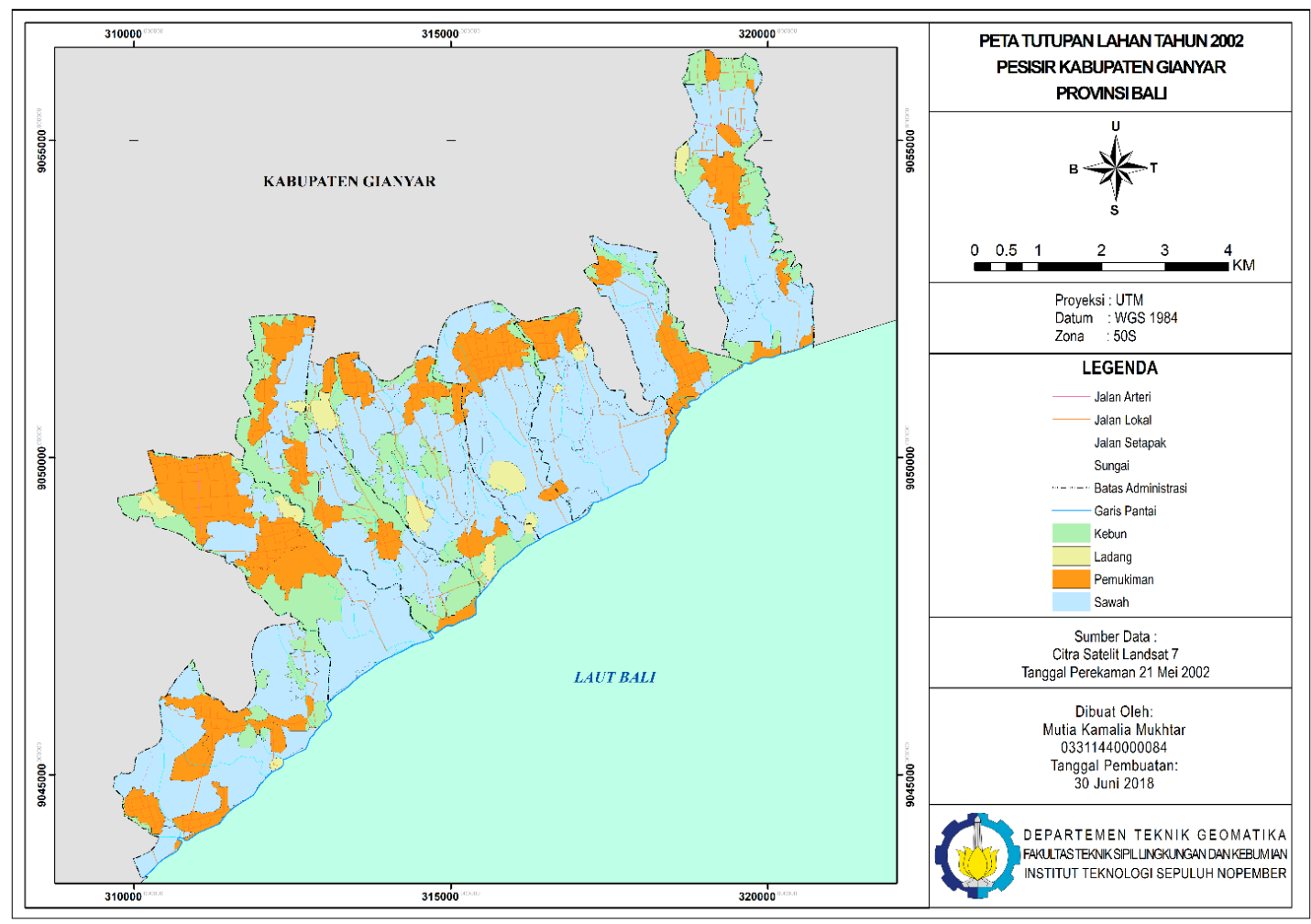

Gambar 7. Peta Tutupan Lahan Tahun 2002

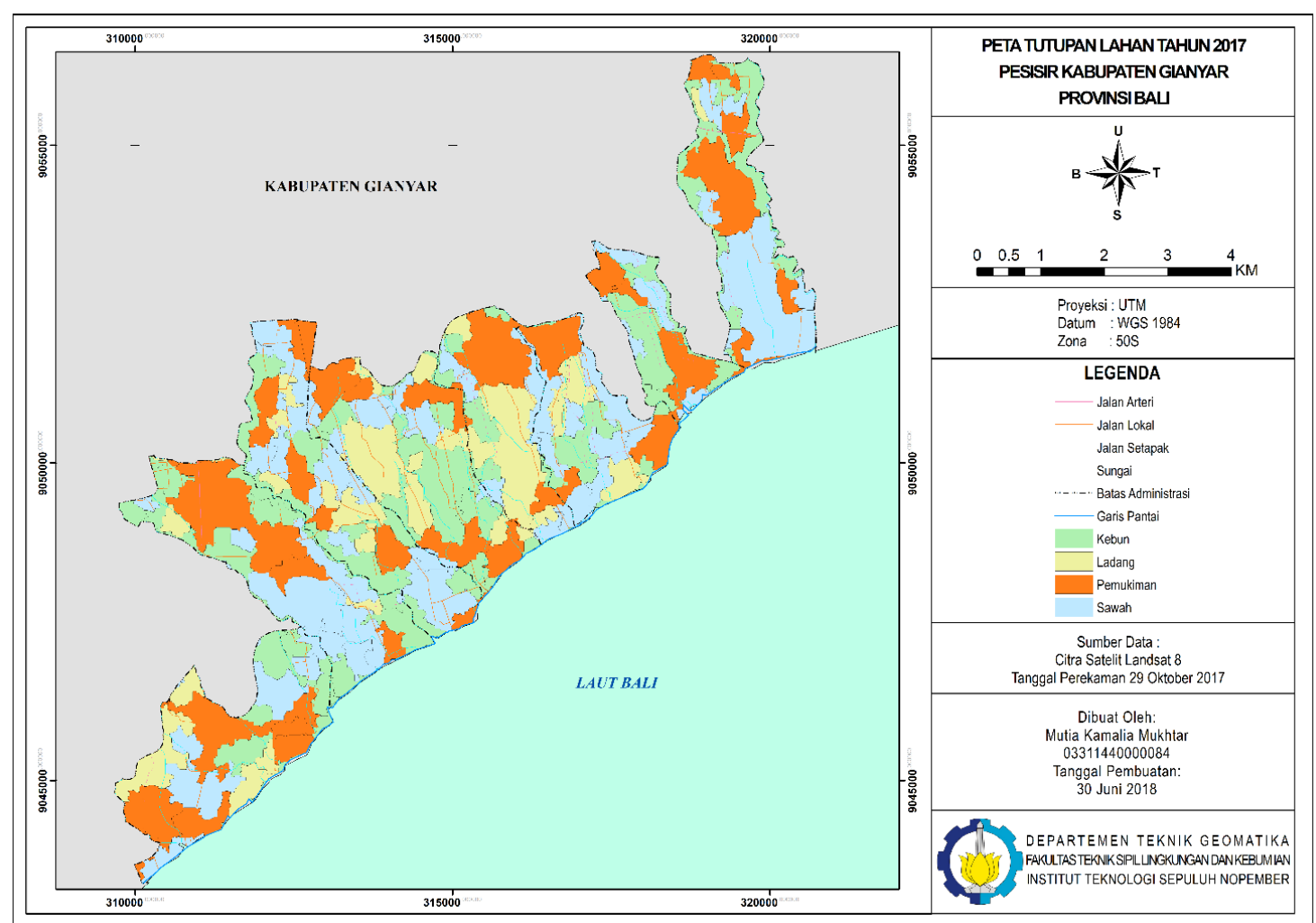

Gambar 8. Peta Tutupan Lahan Tahun 2017 


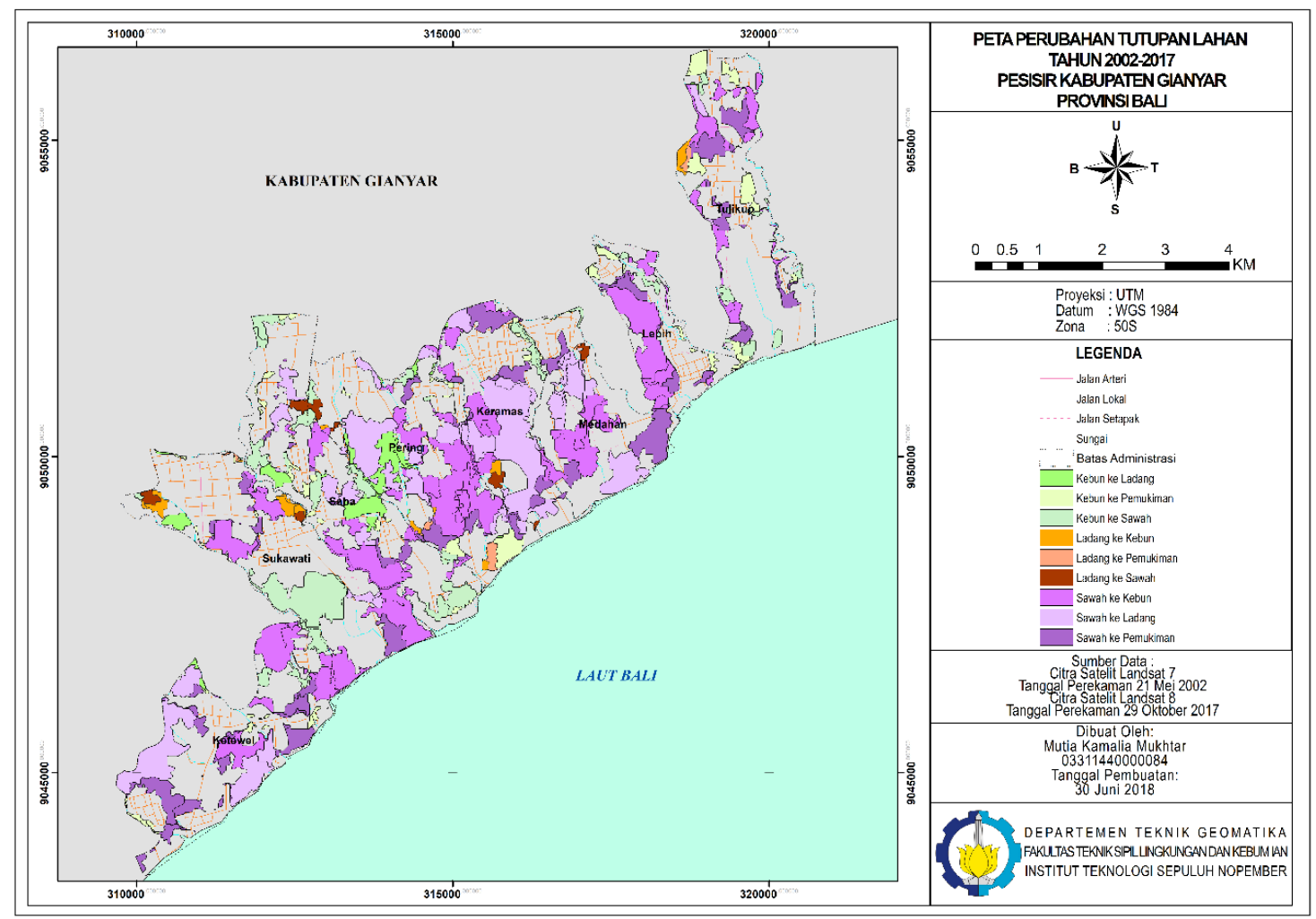

Gambar 9. Peta Perubahan Tutupan Lahan Tahun 2002-2017

Uji akurasi klasifikasi tutupan lahan ini menggunakan data ground truth sebanyak 144 titik pada tahun 2018. Hasil uji akurasi tutupan lahan menggunakan matriks omisi dan komisi menunjukkan hasil sebesar 90,278\% untuk klasifikasi pada citra Landsat 7 tahun 2002 dan 90,972\% untuk klasifikasi pada citra Landsat 8 tahun 2017.

\section{KESIMPULAN}

Berdasarkan hasil penelitian yang telah dilakukan terdapat beberapa hal yang dapat disimpulkan dalam penelitian ini, yaitu :

1. Berdasarkan pengolahan citra satelit Landsat 7 dan 8 yang dilakukan dengan metode band ratio, dapat dibuat peta perubahan garis pantai Kabupaten Gianyar tahun 2002-2017. Hasil pengolahan citra satelit Landsat 7 dan 8 menunjukkan luas abrasi yang terjadi cukup besar dari tahun 2002 sampai 2017 adalah sebesar $0,195 \mathrm{~km}^{2}$. Desa yang paling banyak terkena abrasi adalah Desa Ketewel sebesar $0,065 \mathrm{~km}^{2}$ Desa Tulikup sebesar 0,040 km², Desa Lebih sebesar $0,026 \mathrm{~km}^{2}$, Desa Sukawati sebesar $0,025 \mathrm{~km}^{2}$, Desa Saba sebesar $0,015 \mathrm{~km}^{2}$, Desa Medahan sebesar $0,011 \mathrm{~km}^{2}$, Desa Keramas $0,007 \mathrm{~km}^{2}$, dan yang paling sedikit terkena abrasi adalah Desa Pering sebesar 0,006 km². Perubahan garis pantai akibat abrasi terjadi murni karena faktor alam yaitu pantai yang terletak pada zona laut lepas.

2. Berdasarkan pengolahan citra satelit Landsat 7 dan 8 menggunakan klasifikasi supervised dapat dibuat peta perubahan tutupan lahan pesisir Kabupaten Gianyar tahun 2002-2017. Perubahan ini terjadi akibat adanya perubahan fungsi lahan yang mana terjadi penambahan sebesar 1,603 $\mathrm{km}^{2}$ untuk pemukiman, pengurangan sebesar $10,674 \mathrm{~km}^{2}$ untuk sawah, penambahan sebesar $3,287 \mathrm{~km}^{2}$ untuk kebun, dan penambahan sebesar $5,625 \mathrm{~km}^{2}$ untuk ladang.

\section{DAFTAR PUSTAKA}

Alesheikh, dkk, 2007. Coastline Change Detection Using Remote Sensing, Int. J. Environ. Sci. Tech., 4 (1): 61-66, 2007, ISSN: 1735-1472, (C) Winter 2007, IRSEN, CEERS, IAU.

Anugrahadi, A, dkk. 2012. Analisis Citra Aster GDEM untuk Mengetahui Slope di Daerah yang Terkena Abrasi dan Akresi. Pertemuan IImiah Tahunan (PIT) ISOI IX (Ikatan Sarjana Oseanologi Indonesia) 21-23 Oktober 2012 di Mataram, Lombok. 
Bappeda. (2014). Gambaran Umum Kabupaten Gianyar $<$ https://bappeda.gianyarkab.go.id/index.ph $\mathrm{p} /$ baca-artikel/3/Gambaran-UmumKabupaten-Gianyar.html> Dikunjungi pada 11 April 2018 pukul 14.15

Chand, P., and Acharya, P. 2010. Shoreline Change and Sea Level Rise Along Coast of Bhitarkanika Wildlife Sanctuary, Orissa: An Analytical Approach of Remote Sensing and Statistical Techniques. Int J Geom and Geosci.

Kusumowidagdo, M., dkk. 2007. Penginderaan Jauh dan Interpretasi Citra. Semarang: LAPAN dan UNNES.

Nugraha, I. N. J., dkk. 2016. Ekstraksi Garis Pantai Menggunakan Citra Satelit Landsat Dipesisir Tenggara Bali (Studi Kasus Kabupaten Gianyar Dan Klungkung). Fakultas Kelautan dan Perikanan Universitas Udayana: Prosiding Seminar Kelautan 2016.

Purwadhi, F., dan Hardiyanti, S. 2001. Interpretasi Citra Digital. Jakarta: PT Grasindo

Sutanto. 1994. Penginderaan Jauh Jilid 2. Gadjah Mada. University Press. Jogjakarta.

Undang-Undang Republik Indonesia Nomor 23 Tahun 2014 Tentang Pemerintahan Daerah.

USGS. 2017. Landsat Collection 1 Level 1 Product Definition.

Vreugdenhil, C. B. 1999. Transport Problems in Shallow Water Battleneeks and Appropriate Modeling. Twente University, Department of Civil Engineering and Management, Seminar on Sediment Transport Modelling. 